\title{
Product Knowledge Review on the Purchase Decision
}

\author{
Erny Rachmawati \\ Faculty of Economics and Business Universitas Muhammadiyah Purwokerto \\ Student of Doctoral Program Universitas Jenderal Soedirman \\ ernyrachmawati67@gmail.com
}

\begin{abstract}
The purpose of this article is to illustrate the relationship between product knowledge and purchasing decisions. The method studies the understanding of knowledge, products and product knowledge. The discussion of product knowledge research results a description of the relationship between product knowledge with the purchase decisions.
\end{abstract}

\section{Keywords: $\quad$ Knowledge, products, product knowledge, purchasing decisions}

\section{INTRODUCTION}

Product knowledge is part of the consumer decisionmaking process. Understanding the knowledge that discusses the product can produce product knowledge, but the level of product knowledge among consumers is different. Product knowledge is considered an important source of competitive advantage in the business world so it needs to improve the protection of that knowledge, as it is a part that affects all phases of the decision-making process.

\section{METHOD}

This article begins with the preliminary discourse followed by writing method which uses literature review approach, discussion of result and discussion, concluding with conclusion. Discussions and results contain the studies of knowledge and products, and product knowledge reviews. The study of product knowledge research ended the study of the correlation between product knowledge with the purchase decision.

\section{RESULT}

Understanding knowledge and products

According to [1], knowledge means the fact or condition of knowing something with the familiarity gained through experience. The use of a repeating product will make a person more experienced so as to become familiar with the product. The familiarity of use of the product will form a keahlian. According to [2], the application of knowledge is a process that involves the use of knowledge to decision-making and problemsolving. Knowledge is considered an important source of sustainable competitive advantage for modern business, so it needs to increase attention to the protection of knowledge to prevent being copied by competitors.

The product, according to [3], is a set of tangible and intangible attributes in which color, price, packaging, factory prestige, retailer prestige and service from factories and retailers, which may be accepted by the buyer as something that satisfies his wishes. [4] defines the product as everything that can be offered to the market to get attention, bought, used, or consumed that can satisfy wants or needs. [5], explains that companies that have the greatest need to involve product users depend on the product category (knowledge), because there is a big difference between product categories.

\section{Level of product knowledge}

According to [6] knowledge is as a collection of various kinds of information about the product. Consumers have different levels of product knowledge that consumers use to interpret new information and make purchasing decisions. None of the levels of knowledge include all meanings of objects, events or behaviors. Consumers view product attributes as a means or tool for a specific purpose. Consumers can have product knowledge at four levels: product class, product form, brand, and model or product features. Consumers can also have three types of product knowledge derived from knowledge of the attributes or characteristics of the product, due to the benefits of product use, and the achievement of consumer value of the product, but there is a division by product category.

\section{Research on product knowledge}

Product knowledge [7] stems from memories or knowledge known to the consumer, as it relates to the usage situation. a) Subjective knowledge as perceived knowledge is related to the impetus in the processing of product information, so subjective knowledge means the individual's perception of how much he knows. b) Objective knowledge related to actual information processing capabilities. Objective knowledge is the number, type, or organization of what individuals store in memory. c) Experience-based knowledge means the amount of experience purchased or usable with the product.

According to Sujan [8], on the knowledge of product categories, products are considered to consist of discrete 
attributes and each attribute has a different subjective value. According to [9], product knowledge that uses two constructs is objective knowledge (information about a product stored in the consumer's memory) and subjective knowledge (how many people perceive a product based on interpretation). Knowledge of the product as a subjective knowledge of consumers are found in Lin [10] and Kolyesnikova [11]. Objective and subjective product knowledge such as Cilingir [12]. Knowledge of products with the amount of experience purchasing or using the product as knowledge of experience such as in Park [13].

According to Baker [14] there are 3 knowledge of product categories that are brand knowledge, attribute knowledge, and experiential knowledge. The three dimensions of consumer product knowledge are different and tend to have different effects on consumer behavior.

According to Brucks [15], product knowledge as attribute knowledge includes knowledge of the features or attributes of any product, regardless of whether the consumer uses this feature to make a decision. Information on the evaluation of attributes and how these attributes are related to each other and to performance criteria are included in attribute knowledge. [12] defines overall product knowledge that includes information about functional attributes of product classes and brand differences in product attributes.

Knowledge of products according to Alba [16] is a complex, multidimensional construct is characterized by the structure and content of information stored in memory as knowledge of familiarity and expertise. Knowledge of experience that refers to an awareness of how a product can be used, as well as personal use and personal recognition, product knowledge consists of a) familiarity, i.e. the amount of experience related to products is accumulated by consumers, and b) expertise, as the ability to perform product related to tasks with success. According to [17], knowledge of intimacy is obtained through consumers who have knowledge of tea drinks.

According to Lin [10], product knowledge depends on the awareness or understanding of the product, or consumer beliefs about the product in it.

According to Liu [18], product knowledge means knowing the knowledge of product specifications (e.g. architectural products, technology, materials, etc.), and such knowledge enables customers to explain propositions / uses terms (or requirements) deemed appropriate by the designer. In contrast, the experience of using products refers to personal customers where the direct perception is derived from using different products.

The linkage between product knowledge and purchasing decisions [9], product knowledge is an important factor in the consumer decision making, because it can affect how consumers access the product. Lachman [19] says that consumers have different levels of product knowledge to interpret new information and make purchasing decisions. This opinion is derived from some previous research which use the intention of knowledge of various products and levels of knowledge are quite varied. Although Brucks [7] divides product knowledge into several, but product knowledge is positively associated with product purchase decisions.

According to Lin [10], product knowledge positively affects purchasing decisions. The research was located at Tamsui station, and Train Station in Taipei City. Data collection was gained through questionnaires. From the 400 questionnaires collected were 369 . The results of factor analysis and correlation indicated that product knowledge had a significant positive effect on consumer buying decisions under different product involvement levels.

$\mathrm{Gu}$ [20], examines the relative external and internal impact of WOM (Online word-of-mouth) on retail sales for high-involving products using sales panels and WOM data for 148 digital cameras, the result of user experience (product knowledge), and product reviews have become a key source of information in consumer purchase decisions.

Liang [17] studied tea drinks with 400 volunteer respondents to 332. As a result, consumer product knowledge correlates positively with impulse buying behaviors meaning that the higher level of consumer product knowledge, the higher the behavior impulse buy them.

Hamdan [21] selected respondents who bought food at eight supermarkets in Dungun district, Terengganu. Product knowledge (halal processed foods) can influence the purchasing decisions of Muslim consumers, so product knowledge (familiarity) is identified as the most influential factor in determining purchasing decisions among Muslim consumers.

Javed [22] researching fabric, electronics, and cosmetics products, in Pakistan, it is Country-of-Origin that influences customer purchasing decisions for three different product categories based on Lin \& Chen [10] that product knowledge is derived from consumer memories or customer knowledge of what is known. This product knowledge is associated with customer awareness and by understanding the product by the customer or the consumer's trust in the product. The result is that product knowledge is positively associated with product purchasing decisions.

Yunus [23], the existence of halal products from a variety of local and imported foods produced and handled by a number of ethnic groups, by investigating the determinants of consumers in considering buying packaged kosher foods produced by non-Muslim producers, as well as investigating how halal awareness, orientation of Islam and products of material. The results include product knowledge (material) is important because it allows acceptance or rejection during the purchase decision process.

Not all research product knowledge on homogeneous products. The research on homogeneous products is still limited as Sujan [8] examines the use of cameras. Baker [14] examine the use of DVD player products called fictitious brands. Heterogeneous product research such as Bei [24] examines the powder coffee product classes, jeans and loudspeakers. Park [13] examines the 
characteristics of hedonic products: blue jeans, and utilitarian products: computers. Lin [10] examines insurance and catering services. In conclusion, the research on homogeneous products, such as food groups or consumption product categories, is needed.

\section{CONCLUSION}

Knowledge of the product can be interpreted variously such as subjective knowledge, objective knowledge, knowledge of experience, knowledge of familiarity, knowledge of expertise, knowledge based on the product category, knowledge based on the attribute or product characteristic, knowledge about product specification. In accordance with the theory of consumer behavior, product knowledge is part of the decisionmaking process, so it is said that product knowledge can influence purchasing decisions.

\section{REFERENCES}

[1] Wirtz, Jochen, and Anna S. Mattila. "The effects of consumer expertise on evoked set size and service loyalty." Journal of Services Marketing 17.7: 649665. (2003)

[2] Ha, S. T., Lo, M. C., \& Wang, Y. C. Relationship between knowledge management and organizational performance: a test on SMEs in Malaysia. Procedia-Social and Behavioral Sciences, 224, 184-189. (2016).

[3] Stanton, William J., Michael J. Etzel, and B. J. Walker. "Fundamentals of Marketing, MacGraw Hill." International Edition (1991).

[4] Kotler, Philip, and Gary Armstrong. Principles of marketing. Pearson education, 2010.

[5] Stenmark, Petter, Mats Tinnsten, and Håkan Wiklund. "Customer involvement in product development: Experiences from Scandinavian outdoor companies." Procedia Engineering 13: 538-543. (2011)

[6] Peter, J. P., \& Olson, J. C.. Consumer Behavior and Marketing Strategy, McGraw-Hill. (2010)

[7] Brucks, Merrie. "The effects of product class knowledge on information search behavior." Journal of consumer research: 1-16. (1985)

[8] Sujan, Mita. "Consumer knowledge: Effects on evaluation strategies mediating consumer judgments." Journal of Consumer Research: 31-46. (1985)

[9] Rao, Akshay R., and Kent B. Monroe. "The moderating effect of prior knowledge on cue utilization in product evaluations." Journal of consumer research 15.2: 253-264. (1988)

[10] Lin, Long-Yi, and Chun-Shuo Chen. "The influence of the country-of-origin image, product knowledge and product involvement on consumer purchase decisions: an empirical study of insurance and catering services in Taiwan." Journal of consumer Marketing 23.5: 248-265. (2006)

[11] Kolyesnikova, Natalia, Tim H. Dodd, and Debra A. Laverie. "Gratuity purchasing at wineries: an investigation of the determining factors." International Journal of Wine Business Research 19.4: 239-256. (2007)

[12] Cilingir, Zuhal, and Cigdem Basfirinci. "The impact of consumer ethnocentrism, product involvement, and product knowledge on country of origin effects: An empirical analysis on Turkish consumers' product evaluation." Journal of International Consumer Marketing 26.4: 284-310. (2014)

[13] Park, Chan-Wook, and Byeong-Joon Moon. "The relationship between product involvement and product knowledge: Moderating roles of product type and product knowledge type." Psychology \& Marketing 20.11: 977-997. (2003)

[14] Baker, Thomas L., James B. Hunt, and Lisa L. Scribner. "The effect of introducing a new brand on consumer perceptions of current brand similarity: the roles of product knowledge and involvement." Journal of Marketing Theory and Practice 10.4: 4557. (2002)

[15] Brucks, Merrie. "A typology of consumer knowledge content." ACR North American Advances (1986).

[16] Alba, J. W., \& Hutchinson, J. W. Dimensions of consumer expertise. Journal of consumer research, 13(4), 411-454. (1987).

[17] Liang, Ying-Ping. "The relationship between consumer product involvement, product knowledge and impulsive buying behavior." Procedia-Social and Behavioral Sciences 57: 325-330. (2012)

[18] Liu, Ang, Stephen Lu, and Wei Wei. "A new framework of ideation-oriented customer involvement." Procedia CIRP 21: 521-526. (2014)

[19] Lachman, Roy, Janet L. Lachman, and Earl C. Butterfield. Cognitive psychology and information processing: An introduction. Psychology Press, 2015.

[20] Gu, Bin, Jaehong Park, and Prabhudev Konana. "Research note - the impact of external word-ofmouth sources on retailer sales of high-involvement products." Information Systems Research 23.1: 182196. (2012)

[21] Hamdan, Haslenna, et al. "Purchasing decisions among Muslim consumers of processed halal food products." Journal of Food Products Marketing 19.1): 54-61. (2013)

[22] Javed, Asad, and Syed Amjad Fari Hasnu. "Impact of country-of-origin on product purchase decision." Journal of Marketing and Consumer Research 1: 31-51. (2013)

[23] Yunus, Nor Sara Nadia Muhamad, et al. "Muslim's purchase intention towards non-Muslim's Halal packaged food manufacturer." Procedia-Social and Behavioral Sciences 130: 145-154. (2014)

[24] BEI, L. T., \& Widdows, R. (. Product knowledge and product involvement as moderators of the effects of information on purchase decisions: A case study using the perfect information frontier approach. Journal of Consumer Affairs, 33(1), 165186. 1999). 